\title{
Osteoblast Role in Rheumatic Diseases
}

\author{
Addolorata Corrado, Nicola Maruotti and Francesco Paolo Cantatore * \\ Rheumatology Clinic, Department of Medical and Surgical Sciences, University of Foggia Medical School, \\ 71122 Foggia, Italy; ada.corrado@unifg.it (A.C.); nicomaruotti@libero.it (N.M.) \\ * Correspondence: francescopaolo.cantatore@unifg.it; Tel./Fax: +39-0881-733-164
}

Received: 14 May 2017; Accepted: 12 June 2017; Published: 15 June 2017

\begin{abstract}
Alterations in osteoblast growth, differentiation and activity play a role in the pathogenesis of several rheumatic diseases, such as rheumatoid arthritis, spondyloarthritides, osteoarthritis, and osteoporosis. In fact, in these rheumatic diseases, abnormal activity of Wnt signaling, receptor activator of nuclear factor- $\mathrm{kB}$ (RANK)-RANK ligand (RANKL)-osteoprotegerin (OPG) signaling, bone morphogenetic proteins (BMPs) pathway and other mechanisms have been described in osteoblasts. This review article is focused on current knowledge on the role of osteoblast dysregulation occurring in rheumatic diseases.
\end{abstract}

Keywords: arthritis; osteoarthritis; osteoblast; osteoporosis; spondyloarthritis

\section{Introduction}

Osteoblasts play a role in the pathogenesis of several rheumatic diseases. Alterations in osteoblast growth, differentiation and activity have been described in chronic inflammatory diseases, such as rheumatoid arthritis (RA) and spondyloarthritides (SpA); in degenerative joint diseases, such as osteoarthritis (OA); and bone diseases, such as osteoporosis. This review article is focused on analysis of the current knowledge on the role of osteoblast dysregulation occurring in rheumatic diseases.

\section{Osteoblast Physiology}

Osteoblasts are mononuclear specialized cells originated from pluripotent mesenchymal stem cells differentiation via activation of specific signaling transcription pathways, such as osterix (Osx), Runt-related transcription factor 2 (Runx-2), and Wnt pathway [1].

Osteoblasts play a key role in the regulation of bone metabolism. In fact, they are involved in the production of bone matrix constituents, such as type I collagen. Subsequently, osteoblasts influence calcium and phosphate local concentrations and induce the following bone matrix mineralization [2,3]. Moreover, osteoblasts produce sialoprotein, osteopontin and osteocalcin, which have been associated with the mineralized matrix in vivo [1,4].

On the other hand, osteoblasts are involved in osteoclast regulation by expressing on their membrane or releasing as soluble factor, receptor activator of nuclear factor (NF)- $\mathrm{kB}$ ligand (RANKL).

The interaction between RANKL and receptor activator of nuclear factor- $\mathrm{kB}$ (RANK), a type I transmembrane receptor expressed on osteoclast precursors, is responsible for inducing osteoclast precursor differentiation into osteoclast. The binding of RANKL to RANK leads to the trimerization of RANK and the activation of tumor necrosis factor (TNF) receptor-associated factor 6 (TRAF6). Subsequently, TRAF6 induces the activation of NF- $\mathrm{BB}$ and mitogen-activated protein kinases (MAPKs), such as p38 and Jun N-terminal kinase (JNK), which are, in turn, involved in the activation of transcription factors such as c-Fos, c-Src, and microphtalmia transcription factor (MITF) [5-7]. Furthermore, osteoblasts may modulate osteoclastogenesis through the production of osteoprotegerin (OPG). OPG is a soluble decoy receptor for RANKL, which is responsible for a competitive inhibition of RANK/RANKL link, thus avoiding RANK activation [8]. 
Numerous physiological osteoblast aspects, such as osteoblastogenesis and OPG expression are regulated by the Wnt/ $\beta$-catenin signaling pathway [9-11]. Wnt binding to its coreceptor complex located at the cell surface, which is constituted by the low-density lipoprotein receptor-related proteins 5 (LRP-5) or 6, and a member of the frizzled (Fz) family of proteins, induces Frizzled activation and the recruitment of cytosolic Disheveled (Dvl) proteins [12,13]. Cytosolic $\beta$-catenin is phosphorylated by glycogen synthase kinase 3 (GSK3) and casein kinase 1 (CK1), which form a complex together with Axin and the tumor suppressor adenomatous polyposis coli (APC) [14]. $\beta$-catenin phosphorilation favors its subsequent degradation via ubiquination. Dvl inhibits $\beta$-catenin degradation and allows its cytoplasmic accumulation and nuclear translocation. In the nucleus, $\beta$-catenin is involved in activating the expression of several target genes [11,15-17]. Wnt signaling is inhibited by secreted Fz-related protein family (sFRP) and Wnt inhibitory factor-1 (WIF-1) [18], which block the interaction of Wnt with its receptor Fz. Moreover, LRP5/6 is blocked by proteins of the Dickoppf (DKK) family and by sclerostin, a glycoprotein that is mainly secreted by osteocytes [19].

Osteoclastogenesis regulation involves also several other molecules produced by osteoblasts, such as interleukin-1 (IL-1), TNF- $\alpha$, and macrophage-colony stimulating factor (M-CSF). IL-1 in the presence of adequate levels of RANKL is a potential regulator of osteoclastogenesis. In osteoclast precursor and marrow stromal cells, IL-1 may activate p38 MAP-kinase, which plays a role in TNF- $\alpha$-mediated osteoclastogenesis [20]. TNF- $\alpha$ stimulates RANKL production both directly by producing factors such as TRAF6, RANK, and NF- $\mathrm{KB}$, which are responsible for the activation of osteoclast precursor cells in the early phase of osteoclastogenesis, and indirectly by stimulating osteoclastogenesis-supporting mesenchymal cells [21-24]. TNF receptor type I (TNFRI) and TNF receptor type II (TNFRII) are involved in TNF- $\alpha$ biological activity. Nevertheless, only TNFRI seems to be involved in RANKL-induced osteoclastogenesis, as suggested by the suppression of RANKL-induced osteoclastogenesis after addition of neutralizing anti-TNFRI, but not anti-TNFRII antibodies $[25,26]$. M-CSF has a role in recruiting osteoclasts, as observed in mice with mutation in the coding region of the M-CSF, which were affected by osteoclast-deficient osteopetrosis [27]. M-CSF may activate c-fms, a tyrosine kinase receptor that in turn promotes ERK1/2 and PI3-K/AKT activation, two signaling pathways involved in osteoclast differentiation [28]. Moreover, M-CSF induces osteoclast differentiation via inducing the expression of RANK on pre-osteoclasts surface [29].

A further control in the regulation of RANKL and OPG expression in osteoblasts is played by vitamin D, calcitonin, estrogen, parathormon (PTH), serotonin and leptin [1]. Osteoblast growth and differentiation is also regulated by bone morphogenetic proteins (BMPs), such as BMP-2, BMP4 and BMP-7 which are multi-functional growth factors that belong to the transforming growth factor- $\beta$ (TGF- $\beta$ ) superfamily [1].

\section{Osteoblast Role in RA}

RA is characterized by an increase in bone resorption and impaired bone formation. This imbalanced bone remodeling has been observed both in the subchondral and periarticular bone of joints, where it results in erosions and periarticular osteopenia, and in the axial and appendicular skeleton, where it results in a generalized bone loss.

\subsection{Focal Articular Bone Loss}

Even if other cells, such as osteoclasts, macrophages, and synovial fibroblasts, are mainly involved in these manifestations, osteoblasts probably play a role in the pathogenesis of bone erosions in RA. By using hystomorphometric analysis in a murine model of RA, Walsh et al. [30] have observed that the rate of bone formation in bone surfaces adjacent to inflammation were similar to those observed in non-arthritic bone, suggesting that osteoblasts are not able to balance osteoclast resorption. Moreover, within arthritic bone, the extension of mineralization in the newly formed bone was reduced in areas adjacent to inflammation compared with bone surfaces adjacent to normal marrow, suggesting that inflammation modifies osteoblast physiology. 
In arthritic joints, the bone microenvironment is exposed to reduced $\mathrm{pH}$ and hypoxia. By considering that acidosis and hypoxia down-regulate osteoblast production of alkaline phosphatase and inhibit mineralization in murine osteoblast cultures [31,32], it is conceivable that osteoblasts exposed to the same conditions in the arthritic joint bone microenvironment, may be characterized by reduced activity. In particular, hypoxia inhibits Wnt signaling in osteoblast-like cells, both directly, by inhibiting transcriptional activity via blocking $\beta$-catenin [33], and indirectly, by the up-regulation of DKK-1 [34].

TNF- $\alpha$ and Wnt signaling pathway are probably involved in osteoblast maturation and functions at sites of bone erosions. TNF- $\alpha$ is probably involved in dysregulation of Wnt signaling via inducing DKK-1 over-expression in synovial fibroblast cells [35]. In RA murine models, high levels of TNF- $\alpha$ have been associated with increased levels of DKK-1, and the treatment with DKK-1 antibodies has shown protective effects against bone erosions, suggesting that this is related to the inhibition of the negative regulation of osteoblast maturation and activity [35]. Sclerostin, an inhibitor of the Wnt signaling, inhibits osteoblast differentiation. By using human TNF $\alpha$ transgenic (hTNFtg) mice affected by RA-like disease, Wehmeyer et al. [36] found that the lack of sclerostin or its antibody-mediated inhibition were responsible for an enhanced pannus formation and joint destruction.

TNF- $\alpha$ administration in vitro inhibits osteoblast-related matrix mineralization [37]. Moreover, TNF- $\alpha$ is responsible for a reduction in collagen type I synthesis, in alkaline phosphatase activity, and in osteocalcin expression in vitro [38-40]. An anti-osteoblastic effect has been also described for IL-6, which is most likely mediated by its negative interaction with Wnt signaling pathway [41].

The exposition of osteoblast-like cells to sera of RA patients treated with TNF- $\alpha$ inhibitors has been associated to a reduced synthesis of IL-6, a cytokine directly responsible for arthritis-related bone loss [42]. The same results were obtained also by direct administration of TNF- $\alpha$ inhibitors to osteoblast cultures [43].

The osteoblast expression of pro-inflammatory cytokines, such as IL-1, IL-6, and IL-8, is also favored by adiponectin. Adiponectin induces ostoblast production of mediators that drive synovitis and joint destruction such as matrix metallo-proteinase-1 (MMP-1) and MMP-13, and vascular endothelial growth factor (VEGF) [44,45]. Recently, Chen et al. [46] have observed that the pro-inflammatory cytokine Cysteine-rich 61 (Cyr61 or CCN1), a secreted protein from the CCN family, induces VEGF expression in osteoblasts and increases endothelial progenitor cells angiogenesis in RA. Adiponectin is also involved in RA bone remodeling by inhibiting Osx and inducing OPG expression in osteoblasts [44].

Moreover, overexpression of miR-221 has been seen to be involved in inhibition of calvarial osteoblast differentiation and mineralization in vitro. These results suggest that miRNAs derived from inflamed synovial tissues play a key role at erosion sites in signaling pathways that influence bone loss and potentially also compensatory bone formation [47].

\subsection{Generalized Bone Loss}

Osteoporosis is more frequent in RA patients than in the healthy population [48]. In RA patients also affected by osteoporosis, increased levels of RANKL and decreased levels of OPG have been demonstrated [49]. In active RA lower serum osteocalcin, which is a marker of bone formation, and higher crosslinked $N$-telopeptidases of type 1 collagen (NTX) and deoxypyridinoline (DPD), which are markers of bone resorption, have been found compared to controls and patients with inactive rheumatoid arthritis [50]. Among the main factors involved in RA-related osteoporosis are inflammatory cytokines, glucocorticoid therapy, reduced physical activity, low calcium intake, and poor nutrition associated with enhanced basal energy expenditure [48]. In RA, inflammatory cytokines, such as TNF- $\alpha$, IL-1, IL-6, and IL-17 are involved in the activation of osteoclastogenesis via inducing over-expression of RANKL [51].

Even if further studies are needed to better understand the role of osteoblasts in generalized bone loss in osteoporosis, histomorphometric studies have indicated that, in RA patients who have never been treated with glucocorticoids, osteoporosis seems to be due to a decrease in bone formation 
rather than to an increase in bone resorption [52,53], suggesting that a reduction of osteoblast activity is involved in generalized bone loss in RA.

\section{Osteoblast Role in SpA}

Osteoporosis has been reported as a common complication in SpA patients. Reduced physical activity due to joint pain and worsen back mobility, a more frequent incidence of inflammatory bowel diseases with the subsequent intestinal malabsorption, glucocorticoid treatment, and increased levels of inflammatory cytokines, such as TNF- $\alpha$, IL-1, IL-6, and IL-17, play a key role in SpA-related osteoporosis [54].

Despite the frequent evidence of osteoporosis, sites of joint and vertebral inflammation in SpA patients are characterized by increased local bone formation $[55,56]$. Entheses, the attachment sites of tendon, ligament, joint capsule, fascia or muscle to bones, are considered as the primary target tissue for inflammation in these diseases.

TNF- $\alpha$ is involved in the initiation and regulation of the inflammatory response, by inducing inflammatory cytokines such as IL-1 and IL-6, by recruiting immune and inflammatory cells and by inducing the expression of adhesion molecules as suggested by high levels of TNF- $\alpha$ observed in patients with ankylosing spondylitis (AS) and psoriatic arthritis (PsA) $[57,58]$. TNF- $\alpha$ is responsible for inducing osteoclasts differentiation and function, while concomitantly is involved in the osteoblastogenesis inhibition [56]. Other inflammatory cytokines, such as IL-17 and IL-23 play a central role in abnormal bone formation in AS [59]. IL-23 in enthesial tissues is responsible for inducing a subset of enthesial resident $\mathrm{T}$ cells, identified as $\mathrm{ROR} \gamma \mathrm{T}+\mathrm{CD} 3+\mathrm{CD} 4-\mathrm{CD} 8-$, to produce IL-17 and IL-22 [60]. IL-22 is involved in inducing the differentiation of osteoblasts at the enthesial sites from precursors cells [59].

Numerous evidences suggest a role for an abnormal activation of BMPs pathway and Wnt signaling in excessive periosteal and syndesmophyte bone formation in SpA [61-64].

Low levels of inhibitors of Wnt signaling, such as DKK-1 and sclerostin are involved in inducing bone formation in SpA. In AS patients high DKK-1 levels were correlated to a lower syndesmophyte formation in the spine than patients with low DKK-1 levels, suggesting that low DKK-1 levels play a key role in the pathological bone formation in AS [63]. Recently, Kragstrup et al. [65] have suggested a role for IL-20 and IL-24 in decreasing the production of DKK-1 by SpA fibroblast-like synovial cells and inducing mineralization in human osteoblasts. Moreover, Lee et al. [66] have found higher IL-32 $\gamma$ levels in synovial tissues and fluids of AS patients than in patients with RA or OA. They also demonstrated that IL-32 $\gamma$ was involved in inducing osteoblastogenesis and reducing the expression of DKK-1.

Similarly, low sclerostin levels have been found in sera and periarticular bone from AS patients, with an inverse correlation between radiographic progression of bone formation and sclerostin levels [62].

\section{Osteoblast Role in OA}

Several factors involved in bone metabolism are dysregulated in OA. Alterations in the expression of OPG and RANKL have been found in OA osteoblasts [67,68]. Low levels of R-spondin-2 (Rspo-2), a Wnt/ $\beta$-catenin signaling pathway agonist, and high level of sclerostin, have been found in primary human osteoarthritis osteoblast cultures [69,70].

Moreover, an over-expression of RUNX2 and Osx, two transcriptional factors involved in osteoblast differentiation, has been demonstrated in OA [71].

In particular, two subgroups of osteoblasts characterized by a different metabolic status have been described in OA: low OA osteoblasts, which express low levels of prostaglandin E2 (PGE2), IL-6, and OPG, and high RANKL level; high OA osteoblasts, which express high levels of PGE2, IL-6 and OPG, and low RANKL level [72,73]. Low OA subchondral osteoblasts express high levels of ephrin B4 (EphB4) receptor and high levels of membranous RANKL compared to normal and high OA 
osteoblasts $[67,68,74]$. The binding of EphB4 receptor to EphB2 inhibits the production of IL-1 $\beta$, IL-6 and RANKL, but not of OPG $[67,68]$, suggesting a role in abnormal subchondral bone metabolism in OA. Membranous RANKL is enhanced by vitamin D3, PGE2, IL-1 $\beta$, IL-6, and TNF- $\alpha$ [74], suggesting that low OA osteoblasts play a role in favoring bone resorption, and that high OA osteoblasts are responsible for bone formation.

OA subchondral bone osteoblasts induce a defective mineralization and abnormal organization of the extracellular matrix [75], which is characterized by an altered ratio of $\alpha 1$ and $\alpha 2$ chains of type I collagen, with a prevalence of the $\alpha 1$ chain. OA osteoblasts play also a role in the degradation of articular cartilage by producing hepatocyte growth factor (HGF). HGF stimulates the expression of TGF- $\beta$, which induces DKK-2 expression, and inhibits osteoblast response to BMP-2 [76]. As demonstrated in vitro, osteoblasts may also be responsible for abnormal expression of A disintegrin and metalloproteinase with thrombospondin motifs (ADAMTS), MMPs (in particular MMP-13), and cathepsin K involved in the enzymatic degradation of cartilage in OA [77-80].

Moreover, a role for systemic and local factors has been described in OA osteoblasts. In OA subchondral osteoblasts, high alkaline phosphatase activity and high osteocalcin levels have been described [81-84]. In OA, osteoblasts express high levels of leptin [85], which in turn induce the production of alkaline phosphatase and osteocalcin [86]. Moreover, vitamin D supplementation is involved in the production of osteocalcin in osteoarthritic osteoblasts $[84,87,88]$. As demonstrated in vitro, the response of osteoblasts to vitamin D3 stimulation appears to be proportional to the degree of joint damage [84].

OA bone is characterized by alterations of vascularization, which may be responsible for hypoxia. Hypoxia may modify osteoblast phenotype by altering the expression of genes involved in bone matrix regulation, bone remodeling, and bone vasculature [89], favoring the production of leptin, PGE2, cyclooxygenase 2, angiopoietin-like 4, insulin-like growth factor (IGF) binding protein 1 and type II collagen $\alpha 1$ chain $[89,90]$. Osteoblasts are also able to express VEGF, which is probably involved in the pathogenic mechanisms responsible for the typical bone alterations of OA. VEGF expression has been found higher in primary human OA osteoblast cultures than in normal and osteoporotic osteoblasts, both under basal conditions than in the presence of vitamin D3. Moreover, vitamin D3 significantly enhanced VEGF expression in normal and pathological osteoblasts, suggesting the key role of vitamin D3 supplementation in metabolic bone diseases [91].

\section{Osteoblast Role in Osteoporosis}

Osteoporosis is a disorder characterized by an imbalance of bone turnover, resulting in a reduced bone mineral density, alteration of bone microarchitecture and an increased risk of fracture [92].

A pathological imbalance between bone resorption and bone formation, with a prevalent bone resorption has been seen in osteoporosis. Thus, osteoblast and osteoclast play a key role in the pathogenesis of osteoporosis. On one hand, in postmenopausal osteoporosis the reduced bone mineral density is due to the increased bone resorbing activity of osteoclasts induced by estrogen deficiency. In fact, estrogens are involved in favoring osteoblast activity and inhibiting osteoclastogenesis by inducing OPG production and inhibiting several osteoclastogenesis factors, such as IL-1, IL-6, IL-7, and TNF- $\alpha[93,94]$. On the other hand, an insufficient osteoblast activity is involved in senile osteoporosis [95].

Local and systemic factors can play a role in the activity of osteoblasts and osteoclasts leading to an imbalance in resorptive activity [96]. Nevertheless, an increased tyrosine phosphorylation of IGF-1 receptor has been seen in osteoblast cultures obtained from patients affected by osteoporosis [97], suggesting that a constitutive alteration of osteoblast activity is probably involved in the pathogenesis of osteoporosis. Recently, a role for microRNAs (miRNAs), such as miR-221, has been described in osteoporosis. In fact, miR-221 down-regulation has been demonstrated in osteoporosis. Considering miR-221 inhibits expression of RUNX2, a transcriptional factor for osteoblast differentiation, it is conceivable that osteoblast differentiation may be dysregulated in osteoporosis [98]. 
Bisphosphonates, which are commonly used in clinical practice for the treatment of osteoporosis, exert different cellular biochemical effects depending on dosage and their positive effect on bone mineral density could be related both to an increased osteoblast proliferation, and to inhibition of apoptosis of bone forming cells $[4,99]$.

The observation that adipocytes and osteoblasts originate from the same precursors and that increased adipose tissue in bone marrow is associated with decreased bone tissue in osteoporotic patients, suggests a role for adipogenic process in bone loss [100]. Moreover, a reduced differentiation of mesenchimal stem cells in osteogenic cells has been demonstrated in osteoporosis with a compensatory increment of adipocyte differentiation [101-103].

Murine studies have suggested a role for OPG deficiency and upregulation of RANKL in increasing bone resorption [104-106].

One of most common causes of osteoporosis is chronic glucocorticoid therapy. On one hand, chronic glucocorticoid treatment at high dosage is responsible for both inhibiting proliferation and activity of osteoblasts, and favoring apoptosis of osteoblasts and osteocytes [107]. Glucocorticoids probably inhibit bone formation via suppression of Wnt signaling, as suggested by an in vitro study which has observed high levels of DKK-1 mRNA in cultured human osteoblasts treated with dexamethasone [108]. On the other hand, chronic glucocorticoid treatment at high dosage induces osteoclast activation via stimulating RANKL expression and inhibiting OPG production [107].

\section{Effects of Immunosuppressive and Biological Therapies on Osteoblast}

Inflammatory cytokines play a key role in inducing both generalized and local bone loss, resulting in osteoporosis and joint erosions, respectively. In this regard, in inflammatory diseases, such as RA and $\mathrm{SpA}$, neutralization of these cytokines may also exert useful effects on bone cells.

By studying biochemical markers of bone metabolism, anti-TNF- $\alpha$ therapy has shown inhibitory effects on osteoclast activity, while effects on osteoblasts activity are limited [109-114].

An increased osteoblast proliferation has been seen in RA primary osteoblast cell cultures after exposition to the anti-TNF- $\alpha$ monoclonal antibody infliximab [43]. On the contrary, proliferation and metabolic activity of RA osteoblasts has been inhibited by methotexate [43]. Nevertheless, both methotrexate and infliximab have been correlated to a reduced osteoblast production of IL-6, which is involved in osteoclastogenesis [43]. Moreover, IL-6 down-regulation has also been demonstrated in osteoblast cultures exposed to sera of RA patients treated with infliximab [42].

With regard to SpA, Kwon et al. [115] have found a decrease in the number of osteoblast-lineage cells from peripheral blood obtained from AS patients after treatment with infliximab, suggesting a possible useful effect against osteoblastogenesis at the site of inflammation and bone apposition.

\section{Concluding Remarks}

There is accumulating evidence on the role of osteoblasts in RA, SpA, OA and osteoporosis. In fact, osteoblast differentiation, growth and activity are often dysregulated in these diseases. A full understanding of the pathogenic mechanisms involved in osteoblast dysregulation could lead to the development of new therapeutic strategies in these diseases.

Conflicts of Interest: The authors declare no conflicts of interest.

\section{References}

1. Neve, A.; Corrado, A.; Cantatore, F.P. Osteoblast physiology in normal and pathological conditions. Cell Tissue Res. 2011, 343, 289-302. [CrossRef] [PubMed]

2. Boskey, A.L. Matrix proteins and mineralization: An overview. Connect. Tissue Res. 1996, 35, 357-363. [CrossRef] [PubMed]

3. Boskey, A.L. Biomineralization: Conflicts, challenges, and opportunities. J. Cell. Biochem. 1998, 30, 83-91. [CrossRef] 
4. Maruotti, N.; Corrado, A.; Neve, A.; Cantatore, F.P. Bisphosphonates: Effects on osteoblast. Eur. J. Clin. Pharmacol. 2012, 68, 1013-1018. [CrossRef] [PubMed]

5. Kim, H.H.; Lee, D.E.; Shin, J.N.; Lee, Y.S.; Jeon, Y.M.; Chung, C.H.; Ni, J.; Kwon, B.S.; Lee, Z.H. Receptor activator of NF- $\mathrm{KB}$ recruits multiple TRAF family adaptors and activates c-Jun N-terminal kinase. FEBS Lett. 1999, 443, 297-302. [CrossRef]

6. Matsumoto, M.; Sudo, T.; Saito, T.; Osada, H.; Tsujimoto, M. Involvement of p38 mitogen-activated protein kinase signaling pathway in osteoclastogenesis mediated by receptor activator of NF- $\mathrm{kB}$ ligand (RANKL). J. Biol. Chem. 2000, 275, 31155-31161. [CrossRef] [PubMed]

7. Kobayashi, N.; Kadono, Y.; Naito, A.; Matsumoto, K.; Yamamoto, T.; Tanaka, S.; Inoue, J. Segregation of TRAF6-mediated signaling pathways clarifies its role in osteoclastogenesis. EMBO J. 2001, 20, 1271-1280. [CrossRef] [PubMed]

8. Simonet, W.S.; Lacey, D.L.; Dunstan, C.R.; Kelley, M.; Chang, M.S.; Lüthy, R.; Nguyen, H.Q.; Wooden, S.; Bennett, L.; Boone, T.; et al. Osteoprotegerin: A novel secreted protein involved in the regulation of bone density. Cell 1997, 89, 309-319. [CrossRef]

9. Glass, D.A., II; Bialek, P.; Ahn, J.D.; Starbuck, M.; Patel, M.S.; Clevers, H.; Taketo, M.M.; Long, F.; McMahon, A.P.; Lang, R.A.; et al. Canonical Wnt signaling in differentiated osteoblasts controls osteoclast differentiation. Dev. Cell 2005, 8, 751-764. [CrossRef] [PubMed]

10. Bonewald, L.F.; Johnson, M.L. Osteocytes, mechanosensing and Wnt signaling. Bone 2008, 42, $606-615$. [CrossRef] [PubMed]

11. Maruotti, N.; Corrado, A.; Neve, A.; Cantatore, F.P. Systemic effects of Wnt signaling. J. Cell. Physiol. 2013, 228, 1428-1432. [CrossRef] [PubMed]

12. Tamai, K.; Semenov, M.; Kato, Y.; Spokony, R.; Liu, C.; Katsuyama, Y.; Hess, F.; Saint-Jeannet, J.P.; He, X. LDL-receptor-related proteins in Wnt signal transduction. Nature 2000, 407, 530-535. [PubMed]

13. Wehrli, M.; Dougan, S.T.; Caldwell, K.; O’Keefe, L.; Schwartz, S.; Vaizel-Ohayon, D.; Schejter, E.; Tomlinson, A.; DiNardo, S. Arrow encodes an LDL-receptor-related protein essential for Wingless signaling. Nature 2000, 407, 527-530. [PubMed]

14. Moon, R.T.; Bowerman, B.; Boutros, M.; Perrimon, N. The promise and perils of Wnt signaling through $\beta$-catenin. Science 2002, 296, 1644-1646. [CrossRef] [PubMed]

15. Liu, C.; Li, Y.; Semenov, M.; Han, C.; Baeg, G.H.; Tan, Y.; Zhang, Z.; Lin, X.; He, X. Control of bcatenin phosphorylation/degradation by a dual-kinase mechanism. Cell 2002, 108, 837-847. [CrossRef]

16. Yu, X.; Malenka, R.C. $\beta$-catenin is critical for dendritic morphogenesis. Nat. Neurosci. 2003, 6, 1169-1177. [CrossRef] [PubMed]

17. Willert, K.; Jones, K.A. Wnt signaling: Is the party in the nucleus? Genes Dev. 2006, 20, 1394-1404. [CrossRef] [PubMed]

18. Aberle, H.; Bauer, A.; Stappert, J.; Kispert, A.; Kemler, R. $\beta$-catenin is a target for the ubiquitin-proteasome pathway. EMBO J. 1997, 16, 3797-3804. [CrossRef] [PubMed]

19. Westendorf, J.J.; Kahler, R.A.; Schroeder, T.M. Wnt signaling in osteoblasts and bone diseases. Gene 2004, 341, 19-39. [CrossRef] [PubMed]

20. Wei, S.; Kitaura, H.; Zhou, P.; Ross, F.P.; Teitelbaum, S.L. IL-1 mediates TNF-induced osteoclastogenesis. J. Clin. Investig. 2005, 115, 282-290. [CrossRef] [PubMed]

21. Hofbauer, L.C.; Lacey, D.L.; Dunstan, C.R.; Spelsberg, T.C.; Riggs, B.L.; Khosla, S. Interleukin-1 $\beta$ and tumor necrosis factor- $\alpha$, but not interleukin-6, stimulate osteoprotegerin ligand gene expression in human osteoblastic cells. Bone 1999, 25, 255-259. [CrossRef]

22. Abu-Amer, Y.; Erdmann, J.; Kollias, G.; Alexopoulou, L.; Ross, F.P.; Teitelbaum, S.L. Tumor necrosis factor receptors types 1 and 2 differentially regulate osteoclastogenesis. J. Biol. Chem. 2000, 275, 27307-27310. [CrossRef] [PubMed]

23. Lam, J.; Takeshita, S.; Barker, J.E.; Kanagawa, O.; Ross, F.P.; Teitelbaum, S.L. TNF- $\alpha$ induces osteoclastogenesis by direct stimulation of macrophages exposed to permissive levels of RANK ligand. J. Clin. Investig. 2000, 106, 1481-1488. [CrossRef] [PubMed]

24. Kaji, K.; Katogi, R.; Azuma, Y.; Naito, A.; Inoue, J.I.; Kudo, A. Tumor necrosis factor $\alpha$-induced osteoclastogenesis requires tumor necrosis factor receptor-associated factor 6. J. Bone Miner. Res. 2001, 16, 1593-1599. [CrossRef] [PubMed] 
25. Zou, W.; Hakim, I.; Tschoep, K.; Endres, S.; Bar-Shavit, X. Tumor necrosis factor-A mediates RANK ligand stimulation of osteoclast differentiation by an autocrine mechanism. J. Cell. Biochem. 2001, 83, 70-83. [CrossRef] [PubMed]

26. Nakao, A.; Fukushima, H.; Kajiya, H.; Ozeki, S.; Okabe, K. RANKL-stimulated TNF $\alpha$ production in osteoclast precursor cells promotes osteoclastogenesis by modulating RANK signaling pathways. Biochem. Biophys. Res. Commun. 2007, 357, 945-950. [CrossRef] [PubMed]

27. Yoshida, H.; Hayashi, S.; Kunisada, T.; Ogawa, M.; Nishikawa, S.; Okamura, H.; Sudo, T.; Shultz, L.D.; Nishikawa, S. The murine mutation osteopetrosis is in the coding region of the macrophage colony stimulating factor gene. Nature 1990, 345, 442-444. [CrossRef] [PubMed]

28. Faccio, R.; Takeshita, S.; Zallone, A.; Ross, F.P.; Teitelbaum, S.L. c-Fms and the $\alpha \mathrm{v} \beta 3$ integrin collaborate during osteoclast differentiation. J. Clin. Investig. 2003, 111, 749-758. [CrossRef] [PubMed]

29. Boyle, W.J.; Simonet, W.S.; Lacey, D.L. Osteoclast differentiation and activation. Nature 2003, 423, 337-342. [CrossRef] [PubMed]

30. Walsh, N.C.; Reinwald, S.; Manning, C.A.; Condon, K.W.; Iwata, K.; Burr, D.B.; Gravallese, E.M. Osteoblast function is compromised at sites of focal bone erosion in inflammatory arthritis. J. Bone Miner. Res. 2009, 24, 1572-1585. [CrossRef] [PubMed]

31. Utting, J.C.; Robins, S.P.; Brandao-Burch, A.; Orriss, I.R.; Behar, J.; Arnett, T.R. Hypoxia inhibits the growth, differentiation and bone-forming capacity of rat osteoblasts. Exp. Cell Res. 2006, 312, 1693-1702. [CrossRef] [PubMed]

32. Brandao-Burch, A.; Utting, J.C.; Orriss, I.R.; Arnett, T.R. Acidosis inhibits bone formation by osteoblasts in vitro by preventing mineralization. Calcif. Tissue Int. 2005, 77, 167-174. [CrossRef] [PubMed]

33. Almeida, M.; Han, L.; Martin-Millan, M.; O’Brien, C.A.; Manolagas, S.C. Oxidative stress antagonizes Wnt signaling in osteoblast precursors by diverting $\beta$-catenin from $\mathrm{T}$ cell factor- to forkhead box O-mediated transcription. J. Biol. Chem. 2007, 282, 27298-27305. [CrossRef] [PubMed]

34. Colla, S.; Zhan, F.; Xiong, W.; Wu, X.; Xu, H.; Stephens, O.; Yaccoby, S.; Epstein, J.; Barlogie, B.; Shaughnessy, J.D., Jr. The oxidative stress response regulates DKK1 expression through the JNK signaling cascade in multiple myeloma plasma cells. Blood 2007, 109, 4470-4477. [CrossRef] [PubMed]

35. Diarra, D.; Stolina, M.; Polzer, K.; Zwerina, J.; Ominsky, M.S.; Dwyer, D.; Korb, A.; Smolen, J.; Hoffmann, M.; Scheinecker, C.; et al. Dickkopf-1 is a master regulator of joint remodeling. Nat. Med. 2007, 13, 156-163. [CrossRef] [PubMed]

36. Wehmeyer, C.; Frank, S.; Beckmann, D.; Böttcher, M.; Cromme, C.; König, U.; Fennen, M.; Held, A.; Paruzel, P.; Hartmann, C.; et al. Sclerostin inhibition promotes TNF-dependent inflammatory joint destruction. Sci. Transl. Med. 2016, 8, 330ra35. [CrossRef] [PubMed]

37. Panagakos, F.; Fernandez, C.; Kumar, S. Ultrastructural analysis of mineralized matrix from human osteoblastic cells: Effect of tumor necrosis factor- $\alpha$. Mol. Cell. Biochem. 1996, 158, 81-89. [CrossRef] [PubMed]

38. Bertolini, D.R.; Nedwin, G.E.; Bringman, T.S.; Smith, D.D.; Mundy, G.R. Stimulation of bone resorption and inhibition of bone formation in vitro by human tumour necrosis factors. Nature 1986, 319, 516-518. [CrossRef] [PubMed]

39. Centrella, M.; McCarthy, T.L.; Canalis, E. Tumor necrosis factor $\alpha$ inhibits collagen synthesis and alkaline phosphatase activity independently of its effect on deoxyribonucleic acid synthesis in osteoblast-enriched bone cell cultures. Endocrinology 1988, 123, 1442-1448. [CrossRef] [PubMed]

40. Li, Y.P.; Stashenko, P. Proinflammatory cytokines tumor necrosis factor- $\alpha$ and IL-6, but not IL-1, down-regulate the osteocalcin gene promoter. J. Immunol. 1992, 148, 788-794. [PubMed]

41. Malysheva, K.; de Rooij, K.; Lowik, C.W.; Baeten, D.L.; Rose-John, S.; Stoika, R.; Korchynskyi, O. Interleukin 6/Wnt interactions in rheumatoid arthritis: Interleukin 6 inhibits Wnt signaling in synovial fibroblasts and osteoblasts. Croat. Med. J. 2016, 57, 89-98. [CrossRef]

42. Musacchio, E.; Valvason, C.; Botsios, C.; Ostuni, F.; Furlan, A.; Ramonda, R.; Modesti, V.; Sartori, L.; Punzi, L. The tumor necrosis factor- $\alpha$-blocking agent infliximab inhibits interleukin $1 \beta$ (IL-1 $\beta$ ) and IL-6 gene expression in human osteoblastic cells. J. Rheumatol. 2009, 36, 1575-1579. [CrossRef] [PubMed]

43. Corrado, A.; Neve, A.; Marucci, A.; Gaudio, A.; Cantatore, F.P. Combined effects of infliximab and methotrexate on rheumatoid arthritis osteoblastic cell metabolism. Clin. Exp. Med. 2015, 15, 277-283. [CrossRef] [PubMed] 
44. Krumbholz, G.; Junker, S.; Meier, F.M.; Rickert, M.; Steinmeyer, J.; Rehart, S.; Lange, U.; Frommer, K.W.; Schett, G.; Müller-Ladner, U.; et al. Response of human rheumatoid arthritis osteoblasts and osteoclasts to adiponectin. Clin. Exp. Rheumatol. 2017. [PubMed]

45. Lee, Y.A.; Ji, H.I.; Lee, S.H.; Hong, S.J.; Yang, H.I.; Chul Yoo, M.; Kim, K.S. The role of adiponectin in the production of IL-6, IL-8, VEGF and MMPs in human endothelial cells and osteoblasts: Implications for arthritic joints. Exp. Mol. Med. 2014, 46, e72. [CrossRef] [PubMed]

46. Chen, C.Y.; Su, C.M.; Hsu, C.J.; Huang, C.C.; Wang, S.W.; Liu, S.C.; Chen, W.C.; Fuh, L.J.; Tang, C.H. CCN1 promotes VEGF production in osteoblasts and induces endothelial progenitor cell angiogenesis by Inhibiting miR-126 expression in rheumatoid arthritis. J. Bone Miner. Res. 2017, 32, 34-45. [CrossRef] [PubMed]

47. Maeda, Y.; Farina, N.H.; Matzelle, M.M.; Fanning, P.J.; Lian, J.B.; Gravallese, E.M. Synovium-derived microRNAs regulate bone pathways in rheumatoid arthritis. J. Bone Miner. Res. 2017, 32, 461-472. [CrossRef] [PubMed]

48. Maruotti, N.; Corrado, A.; Cantatore, F.P. Osteoporosis and rheumatic diseases. Reumatismo 2014, 66, 125-135. [CrossRef] [PubMed]

49. Xu, S.; Wang, Y.; Lu, J.; Xu, J. Osteoprotegerin and RANKL in the pathogenesis of rheumatoid arthritis-induced osteoporosis. Rheumatol. Int. 2012, 32, 3397-3403. [CrossRef] [PubMed]

50. Seriolo, B.; Ferretti, V.; Sulli, A.; Caratto, E.; Fasciolo, D.; Cutolo, M. Serum osteocalcin levels in premenopausal rheumatoid arthritis patients. Ann. N. Y. Acad. Sci. 2002, 966, 502-507. [CrossRef] [PubMed]

51. Takayanagi, H. Osteoimmunology and the effects of the immune system on bone. Nat. Rev. Rheumatol. 2009, 5, 667-676. [CrossRef] [PubMed]

52. Mellish, R.W.E.; O'Sullivan, M.M.; Garrahan, N.J.; Compston, J.E. Iliac crest trabecular bone mass and structure in patients with nonsteroid treated rheumatoid arthritis. Ann. Rheum. Dis. 1987, 46, 830-836. [CrossRef] [PubMed]

53. Kroger, H.; Arnala, I.; Alhava, E.M. Bone remodeling in osteoporosis associated with rheumatoid arthritis. Calcif. Tissue Int. 1991, 49, S90. [CrossRef] [PubMed]

54. Carter, S.; Lories, R.J. Osteoporosis: A paradox in ankylosing spondylitis. Curr. Osteoporos. Rep. 2011, 9, 112-115. [CrossRef] [PubMed]

55. Lories, R.J.; Schett, G. Pathophysiology of new bone formation and ankylosis in spondyloarthritis. Rheum. Dis. Clin. N. Am. 2012, 38, 555-567. [CrossRef] [PubMed]

56. Neve, A.; Maruotti, N.; Corrado, A.; Cantatore, F.P. Pathogenesis of ligaments ossification in spondyloarthritis: Insights and doubts. Ann. Med. 2017, 49, 196-205. [CrossRef] [PubMed]

57. Braun, J.; Bollow, M.; Neure, L.; Seipelt, E.; Seyrekbasan, F.; Herbst, H.; Eggens, U.; Distler, A.; Sieper, J. Use of immunohistologic and in situ hybridization techniques in the examination of sacroiliac joint biopsy specimens from patients with ankylosing spondylitis. Arthritis Rheumatol. 1995, 38, 499-505. [CrossRef]

58. Partsch, G.; Steiner, G.; Leeb, B.F.; Dunky, A.; Broll, H.; Smolen, J.S. Highly increased levels of tumor necrosis factor- $\alpha$ and other proinflammatory cytokines in psoriatic arthritis synovial fluid. J. Rheumatol. 1997, 24, 518-523. [PubMed]

59. Baum, R.; Gravallese, E.M. Bone as a Target organ in rheumatic disease: Impact on osteoclasts and osteoblasts. Clin. Rev. Allergy Immunol. 2016, 51, 1-15. [CrossRef] [PubMed]

60. Benjamin, M.; McGonagle, D. The anatomical basis for disease localisation in seronegative spondyloarthropathy at enthuses and related sites. J. Anat. 2001, 199, 503-526. [CrossRef] [PubMed]

61. Chen, H.A.; Chen, C.H.; Lin, Y.J.; Chen, P.C.; Chen, W.S.; Lu, C.L.; Chou, C.T. Association of bone morphogenetic proteins with spinal fusion in ankylosing spondylitis. J. Rheumatol. 2010, 37, $2126-2132$. [CrossRef] [PubMed]

62. Appel, H.; Ruiz-Heiland, G.; Listing, J.; Zwerina, J.; Herrmann, M.; Mueller, R.; Haibel, H.; Baraliakos, X.; Hempfing, A.; Rudwaleit, M.; et al. Altered skeletal expression of sclerostin and its link to radiographic progression in ankylosing spondylitis. Arthritis Rheumatol. 2009, 60, 3257-3262. [CrossRef] [PubMed]

63. Heiland, G.R.; Appel, H.; Poddubnyy, D.; Zwerina, J.; Hueber, A.; Haibel, H.; Baraliakos, X.; Listing, J.; Rudwaleit, M.; Schett, G.; et al. High level of functional dickkopf-1 predicts protection from syndesmophyte formation in patients with ankylosing spondylitis. Ann. Rheum. Dis. 2012, 71, 572-574. [CrossRef] [PubMed]

64. Lories, R.J.; Derese, I.; Luyten, F.P. Modulation of bone morphogenetic protein signaling inhibits the onset and progression of ankylosing enthesitis. J. Clin. Investig. 2005, 115, 1571-1579. [CrossRef] [PubMed] 
65. Kragstrup, T.W.; Andersen, M.N.; Schiøttz-Christensen, B.; Jurik, A.G.; Hvid, M.; Deleuran, B. Increased IL-20 and IL-24 target osteoblasts and synovial monocytes in spondyloarthritis. Clin. Exp. Immunol. 2017. [CrossRef] [PubMed]

66. Lee, E.J.; Lee, E.J.; Chung, Y.H.; Song, D.H.; Hong, S.; Lee, C.K.; Yoo, B.; Kim, T.H.; Park, Y.S.; Kim, S.H.; et al. High level of interleukin-32 $\gamma$ in the joint of ankylosing spondylitis is associated with osteoblast differentiation. Arthritis Res. Ther. 2015, 17, 350. [CrossRef] [PubMed]

67. Kwan Tat, S.; Pelletier, J.P.; Amiable, N.; Boileau, C.; Lajeunesse, D.; Duval, N.; Martel-Pelletier, J. Activation of the receptor EphB4 by its specific ligand ephrin B2 in human osteoarthritic subchondral bone osteoblasts. Arthritis Rheumatol. 2008, 58, 3820-3830. [CrossRef] [PubMed]

68. Kwan Tat, S.; Pelletier, J.P.; Lajeunesse, D.; Fahmi, H.; Lavigne, M.; Martel-Pelletier, J. The differential expression of osteoprotegerin (OPG) and receptor activator of nuclear factor $\kappa B$ ligand (RANKL) in human osteoarthritic subchondral bone osteoblasts is an indicator of the metabolic state of these disease cells. Clin. Exp. Rheumatol. 2008, 26, 295-304. [PubMed]

69. Abed, É.; Chan, T.F.; Delalandre, A.; Martel-Pelletier, J.; Pelletier, J.P.; Lajeunesse, D. R-spondins are newly recognized players in osteoarthritis that regulate Wnt signaling in osteoblasts. Arthritis Rheumatol. 2011, 63, 3865-3875. [CrossRef] [PubMed]

70. Abed, É.; Couchourel, D.; Delalandre, A.; Duval, N.; Pelletier, J.P.; Martel-Pelletier, J.; Lajeunesse, D. Low sirtuin 1 levels in human osteoarthritis subchondral osteoblasts lead to abnormal sclerostin expression which decreases Wnt/ $\beta$-catenin activity. Bone 2014, 59, 28-36. [CrossRef] [PubMed]

71. Dragojevič, J.; Logar, D.B.; Komadina, R.; Marc, J. Osteoblastogenesis and adipogenesis are higher in osteoarthritic than in osteoporotic bone tissue. Arch. Med. Res. 2011, 42, 392-397. [CrossRef] [PubMed]

72. Massicotte, F.; Lajeunesse, D.; Benderdour, M.; Pelletier, J.P.; Hilal, G.; Duval, N.; Martel-Pelletier, J. Can altered production of interleukin- $1 \beta$, interleukin-6, transforming growth factor- $\beta$ and prostaglandin $\mathrm{E}_{2}$ by isolated human subchondral osteoblasts identify two subgroups of osteoarthritic patients? Osteoarthr. Cartil. 2002, 10, 491-500. [CrossRef] [PubMed]

73. Tat, S.K.; Padrines, M.; Theoleyre, S.; Couillaud-Battaglia, S.; Heymann, D.; Redini, F.; Fortun, Y. OPG/membranous-RANKL complex is internalized via the clathrin pathway before a lysosomal and a proteasomal degradation. Bone 2006, 39, 706-715. [CrossRef] [PubMed]

74. Tat, S.K.; Pelletier, J.P.; Lajeunesse, D.; Fahmi, H.; Duval, N.; Martel-Pelletier, J. Differential modulation of RANKL isoforms by human osteoarthritic subchondral bone osteoblasts: Influence of osteotropic factors. Bone 2008, 43, 284-291. [CrossRef] [PubMed]

75. Prasadam, I.; Farnaghi, S.; Feng, J.Q.; Gu, W.; Perry, S.; Crawford, R.; Xiao, Y. Impact of extracellular matrix derived from osteoarthritis subchondral bone osteoblasts on osteocytes: Role of integrin $\beta 1$ and focal adhesion kinase signaling cues. Arthritis Res. Ther. 2013, 15, R150. [CrossRef] [PubMed]

76. Abed, É.; Bouvard, B.; Martineau, X.; Jouzeau, J.Y.; Reboul, P.; Lajeunesse, D. Elevated hepatocyte growth factor levels in osteoarthritis osteoblasts contribute to their altered response to bone morphogenetic protein-2 and reduced mineralization capacity. Bone 2015, 75, 111-119. [CrossRef] [PubMed]

77. Sanchez, C.; Deberg, M.A.; Piccardi, N.; Msika, P.; Reginster, J.Y.; Henrotin, Y.E. Osteoblasts from the sclerotic subchondral bone downregulate aggrecan but upregulate metalloproteinases expression by chondrocytes. This effect is mimicked by interleukin- $6,-1 \beta$ and oncostatin $M$ pre-treated non-sclerotic osteoblasts. Osteoarthr. Cartil. 2005, 13, 979-987. [CrossRef] [PubMed]

78. Mandelin, J.; Hukkanen, M.; Li, T.F.; Korhonen, M.; Liljeström, M.; Sillat, T.; Hanemaaijer, R.; Salo, J.; Santavirta, S.; Konttinen, Y.T. Human osteoblasts produce cathepsin K. Bone 2006, 38, 769-777. [CrossRef] [PubMed]

79. Sakao, K.; Takahashi, K.A.; Arai, Y.; Saito, M.; Honjo, K.; Hiraoka, N.; Asada, H.; Shin-Ya, M.; Imanishi, J.; Mazda, O.; et al. Osteoblasts derived from osteophytes produce interleukin-6, interleukin-8, and matrix metalloproteinase-13 in osteoarthritis. J. Bone Miner. Metab. 2009, 27, 412-423. [CrossRef] [PubMed]

80. Prasadam, I.; Crawford, R.; Xiao, Y. Aggravation of ADAMTS and matrix metalloproteinase production and role of ERK1/2 pathway in the interaction of osteoarthritic subchondral bone osteoblasts and articular cartilage chondrocytes-Possible pathogenic role in osteoarthritis. J. Rheumatol. 2012, 39, 621-634. [CrossRef] [PubMed]

81. Mansell, J.P.; Tarlton, J.F.; Bailey, A.J. Biochemical evidence for altered subchondral bone collagen metabolism in osteoarthritis of the hip. Br. J. Rheumatol. 1997, 36, 16-19. [CrossRef] [PubMed] 
82. Hilal, G.; Martel-Pelletier, J.; Pelletier, J.P.; Ranger, P.; Lajeunesse, D. Osteoblast-like cells from human subchondral osteoarthritic bone demonstrate an altered phenotype in vitro: Possible role in subchondral bone sclerosis. Arthritis Rheumatol. 1998, 41, 891-899. [CrossRef]

83. Hilal, G.; Massicotte, F.; Martel-Pelletier, J.; Fernandes, J.C.; Pelletier, J.P.; Lajeunesse, D. Endogenous prostaglandin E2 and insulin like growth factor 1 can modulate the levels of parathyroid hormone receptor in human osteoarthritic osteoblasts. J. Bone Miner. Res. 2001, 16, 713-721. [CrossRef] [PubMed]

84. Cantatore, F.P.; Corrado, A.; Grano, M.; Quarta, L.; Colucci, S.; Melillo, N. Osteocalcin synthesis by human osteoblasts from normal and osteoarthritic bone after vitamin D3 stimulation. Clin. Rheumatol. 2004, 23, 490-495. [CrossRef] [PubMed]

85. Mutabaruka, M.S.; Aoulad Aissa, M.; Delalandre, A.; Lavigne, M.; Lajeunesse, D. Local leptin production in osteoarthritis subchondral osteoblasts may be responsible for their abnormal phenotypic expression. Arthritis Res. Ther. 2010, 12, R20. [CrossRef] [PubMed]

86. Dumond, H.; Presle, N.; Terlain, B.; Mainard, D.; Loeuille, D.; Netter, P.; Pottie, P. Evidence for a key role of leptin in osteoarthritis. Arthritis Rheumatol. 2003, 48, 3118-3129. [CrossRef] [PubMed]

87. Gevers, G.; Dequeker, J. Collagen and non-collagenous protein content (osteocalcin, sialoprotein, proteoglycan) in the iliac crest bone and serum osteocalcin in women with and without hand osteoarthritis. Coll. Relat. Res. 1987, 7, 435-442. [CrossRef]

88. Corrado, A.; Cantatore, F.P.; Grano, M.; Colucci, S. Neridronate and human osteoblasts in normal, osteoporotic and osteoarthritic subjects. Clin. Rheumatol. 2005, 24, 527-534. [CrossRef] [PubMed]

89. Chang, J.; Jackson, S.G.; Wardale, J.; Jones, S.W. Hypoxia modulates the phenotype of osteoblasts isolated from knee osteoarthritis patients, leading to undermineralized bone nodule formation. Arthritis Rheumatol. 2014, 66, 1789-1799. [CrossRef] [PubMed]

90. Bouvard, B.; Abed, E.; Yéléhé-Okouma, M.; Bianchi, A.; Mainard, D.; Netter, P.; Jouzeau, J.Y.; Lajeunesse, D.; Reboul, P. Hypoxia and vitamin D differently contribute to leptin and dickkopf-related protein 2 production in human osteoarthritic subchondral bone osteoblasts. Arthritis Res. Ther. 2014, 16, 459. [CrossRef] [PubMed]

91. Corrado, A.; Neve, A.; Cantatore, F.P. Expression of vascular endothelial growth factor in normal, osteoarthritic and osteoporotic osteoblasts. Clin. Exp. Med. 2013, 13, 81-84. [CrossRef] [PubMed]

92. Raisz, L.A. Pathogeneis of osteoporosis: Concepts, conflicts, and prospects. J. Clin. Investig. 2005, 115, 3318-3325. [CrossRef] [PubMed]

93. Satpathy, S.; Patra, A.; Ahirwar, B. Experimental techniques for screening of antiosteoporotic activity in postmenopausal osteoporosis. J. Complement. Integr. Med. 2015, 12, 251-266. [CrossRef] [PubMed]

94. Jia, J.; Zhou, H.; Zeng, X.; Feng, S. Estrogen stimulates osteoprotegerin expression via the suppression of miR-145 expression in MG-63 cells. Mol. Med. Rep. 2017, 15, 1539-1546. [CrossRef] [PubMed]

95. Beil, F.T.; Seitz, S.; Priemel, M.; Barvencik, F.; Von Domuras, C.; Rueger, J.M.; Amling, M.; Podoga, P. Pathophysiology and pathomorphology of osteoporosis. Eur. J. Trauma Emerg. Surg. 2008, 6, 527-534. [CrossRef] [PubMed]

96. Horwitz, M.C.; Lorenzo, J.A. Local regulators of bone: IL-1, TNF, lymphotoxin, interferon- $\gamma$, IL-8, IL-10, IL-4, the LIF/IL-6 family, and additional cytokines. In Principle of Biology; Bilezikian, J.P., Raisz, L.G., Rodan, G.A., Eds.; Academic Press: San Diego, CA, USA, 2002; pp. 961-977.

97. Perrini, S.; Natalicchio, A.; Laviola, L.; Cignarelli, A.; Melchiorre, M.; de Stefano, F.; Caccioppoli, C.; Leonardini, A.; Martemucci, S.; Belsanti, G.; et al. Abnormalities of insulin like growth factor-I signaling and impaired cell proliferation in osteoblasts from subjects with osteoporosis. Endocrinology 2008, 149, 1302-1313. [CrossRef] [PubMed]

98. Zhang, Y.; Gao, Y.; Cai, L.; Li, F.; Lou, Y.; Xu, N.; Kang, Y.; Yang, H. microRNA-221 is involved in the regulation of osteoporosis through regulates RUNX2 protein expression and osteoblast differentiation. Am. J. Transl. Res. 2017, 9, 126-135. [PubMed]

99. Corrado, A.; Neve, A.; Maruotti, N.; Gaudio, A.; Marucci, A.; Cantatore, F.P. Dose-dependent metabolic effect of zoledronate on primary human osteoblastic cell cultures. Clin. Exp. Rheumatol. 2010, 28, 873-879. [PubMed]

100. Justesen, J.; Stenderup, K.; Ebbesen, E.N.; Mosekilde, L.; Steiniche, T.; Kassem, M. Adipocyte tissue volume in bone marrow is increased with aging and in patients with osteoporosis. Biogerontology 2001, 2, 1665-1671. [CrossRef] 
101. Rodríguez, J.P.; Garat, S.; Gajardo, H.; Pino, A.M.; Seitz, G. Abnormal osteogenesis in osteoporotic patients is reflected by altered mesenchymal stem cells dynamics. J. Cell. Biochem. 1999, 75, 414-423. [CrossRef]

102. Verma, S.; Rajaratnam, J.H.; Denton, J.; Hoyland, J.A.; Byers, R.J. Adipocytic proportion of bone marrow is inversely related to bone formation in osteoporosis. J. Clin. Pathol. 2002, 55, 693-698. [CrossRef] [PubMed]

103. Rodríguez, J.P.; Astudillo, P.; Ríos, S.; Pino, A.M. Involvement of adipogenic potential of human bone marrow mesenchymal stem cells (MSCs) in osteoporosis. Curr. Stem Cell Res. Ther. 2008, 3, 208-218. [CrossRef] [PubMed]

104. Bucay, N.; Sarosi, I.; Dunstan, C.R.; Morony, S.; Tarpley, J.; Capparelli, C.; Scully, S.; Tan, H.L.; Xu, W.; Lacey, D.L.; et al. Osteoprotegerin-deficient mice develop early onset osteoporosis and arterial calcification. Genes Dev. 1998, 12, 1260-1268. [CrossRef] [PubMed]

105. Mizuno, A.; Amizuka, N.; Irie, K.; Murakami, A.; Fujise, N.; Kanno, T.; Sato, Y.; Nakagawa, N.; Yasuda, H.; Mochizuki, S.; et al. Severe osteoporosis in mice lacking osteoclastogenesis inhibitory factor/osteoprotegerin. Biochem. Biophys. Res. Commun. 1998, 247, 610-615. [CrossRef] [PubMed]

106. Eghbali-Fatourechi, G.; Khosla, S.; Sanyal, A.; Boyle, W.J.; Lacey, D.L.; Riggs, B. Role of RANK ligand in mediating increased bone resorption in early postmenopausal women. J. Clin. Investig. 2003, 111, 1221-1230. [CrossRef] [PubMed]

107. Canalis, E. Mechanisms of glucocorticoid-induced osteoporosis. Curr. Opin. Rheumatol. 2003, 15, $454-457$. [CrossRef] [PubMed]

108. Ohnaka, K.; Taniguchi, H.; Kawate, H.; Nawata, H.; Takayanagi, R. Glucocorticoid enhances the expression of dickkopf-1 in human osteoblasts: Novel mechanism of glucocorticoidinduced osteoporosis. Biochem. Biophys. Res. Commun. 2004, 318, 259-264. [CrossRef] [PubMed]

109. Yasunori, K.; Masaaki, T.; Tetsuyuki, N.; Hayato, K.; Akira, N. Reduction of urinary levels of pyridinoline and deoxypyridinoline and serum levels of soluble receptor activator of NF- $\mathrm{kB}$ ligand by etanercept in patients with rheumatoid arthritis. Clin. Rheumatol. 2008, 27, 1093-1101. [CrossRef] [PubMed]

110. Miheller, P.; Muzes, G.; Zagoni, T.; Toth, M.; Racz, K.; Tulassay, Z. Infliximab therapy improves the bone metabolism in fistulizing Crohn's disease. Dig. Dis. 2006, 24, 201-206. [CrossRef] [PubMed]

111. Abreu, M.T.; Geller, J.L.; Vasiliauskas, E.A.; Kam, L.Y.; Vora, P.; Martyak, L.A.; Yang, H.; Hu, B.; Lin, Y.C.; Keenan, G.; et al. Treatment with infliximab is associated with increased markers of bone formation in patients with Crohn's disease. J. Clin. Gastroenterol. 2006, 40, 55-63. [CrossRef] [PubMed]

112. Barnabe, C.; Hanley, D.A. Effect of tumor necrosis factor $\alpha$ inhibition on bone density and turnover markers in patients with rheumatoid arthritis and spondyloarthropathy. Semin. Arthritis Rheumatol. 2009, 39, 116-122. [CrossRef] [PubMed]

113. Veerappan, S.G.; O'Morain, C.A.; Daly, J.S.; Ryan, B.M. Review article: The effects of antitumour necrosis factor- $\alpha$ on bone metabolism in inflammatory bowel disease. Aliment. Pharmacol. Ther. 2011, 33, 1261-1272. [CrossRef] [PubMed]

114. Lange, U.; Teichmann, J.; Muller-Ladner, U.; Strunk, J. Increase in bone mineral density of patients with rheumatoid arthritis treated with anti-TNF- $\alpha$ antibody: A prospective open-label pilot study. Rheumatology 2005, 44, 1546-1548. [CrossRef] [PubMed]

115. Kwon, S.R.; Jung, K.H.; Lim, M.J.; Son, M.J.; Choi, B.H.; Park, S.G.; Park, W. The effect of anti-TNF treatment on osteoblastogenesis in ankylosing spondylitis: The number of circulating osteoblast-lineage cells in peripheral blood decreased after infliximab therapy in patients with ankylosing spondylitis. Clin. Exp. Rheumatol. 2017. [PubMed]

(C) 2017 by the authors. Licensee MDPI, Basel, Switzerland. This article is an open access article distributed under the terms and conditions of the Creative Commons Attribution (CC BY) license (http://creativecommons.org/licenses/by/4.0/). 